\title{
Effects of dormant-season herbage removal on Flint Hills rangeland
}

\author{
LISA M. AUEN AND CLENTON E. OWENSBY
}

\begin{abstract}
Intensive-early stocking in the Kansas Flint Hills has greatly increased livestock production efficiency. The potential grazing of regrowth on intensive-early stocked Flint Hills pastures was studied by monthly mowing to $5-\mathrm{cm}$ height from October to April, 1983-1985. Those treatments had no effect on total nonstructural carbohydrates (TNC) in Andropogon gerardit Vitman rhizomes or on herbage production the following seasons. Since there was no reduction in herbage yield for any mowing date, cattle producers can apparently restock IES pastures after 1 October.
\end{abstract}

Key Words: total nonstructural carbohydrates, Andropogon gerardii, winter removal, near-infrared reflectance spectroscopy

Kansas Flint Hills range is converted to saleable red meat more efficiently by intensive-early (IES) stocking than by season-long stocking. IES results in higher animal gains per hectare without sacrificing individual animal performance. Thus, producers realize more profit compared to season-long systems. In addition, IES cattle can be sold in July, when traditionally fewer cattle are sold and prices are higher.

IES consists of stocking at double the season-long rates during the first half of the growing season, then removing the animals and allowing the forage to regrow the remainder of the season in order to replenish carbohydrate reserves (Launchbaugh and Owensby 1978). Regrowth on IES pastures was responsible for higher herbage yields at the end of the growing season compared to seasonlong stocked pastures (Smith and Owensby 1978). Winter grazing of regrowth on IES pastures would be an alternative to feeding hay and provide producers greater flexibility in purchasing cattle.

The objective of this study was to determine the effects of winter herbage removal on subsequent herbage production and on TNC reserves in big bluestem (Andropogon gerardii Vitman) rhizomes, a key dominant of the Flint Hills.

\section{Materials and Methods}

\section{Location}

The study area was on the Konza Prairie Research Natural Area near Manhattan, Kansas (Hulbert 1985). The plots were located on a loamy upland range site with a Benfield-Florence complex soil (Benfield series: fine, mixed, mesic, Udic Argiustolls; Florence series: clayey-skeletal, montmorillonitic, mesic, Udic Argiustolls). The site was burned by a wildfire in early spring of 1982 .

\section{Vegetation}

The vegetation within the plots was typical of the Flint Hills range ecosystem. The dominant grasses were big bluestem, Indiangrass (Sorghastrum nutans (L.) Nash), and little bluestem (Andropogon scoparius Michx.).

\section{Treatments}

Treatments were mowing and removing herbage or mowing and leaving herbage on different plots on the first of each month from October 1983 to April 1984 and October 1984 to April 1985. These 2 treatments were applied on 7 dates over 2 years. Snow cover eliminated December and February treatments. For comparison

\footnotetext{
The authors are research assistant and professor of range science, Department of Agronomy, Kansas State University, Manhattan 66506.

Contribution No. 88-262-J from the Kansas Agricultural Experiment Station.

Manuscript accepted 11 July 1988.
}

standard plots, herbage was removed on 1 May by burning in 1984 and by mowing and raking in 1985 because of an earlier spring. Hulbert (1969) showed no significant difference between plots denuded by burning and plots denuded by mowing and raking. The $3 \times 3-\mathrm{m}$ plots were mowed to a $5-\mathrm{cm}$ stubble height with a sicklebar mower, and the cut herbage was either raked off or returned evenly over the plots.

\section{Herbage Production}

Herbage production for all treatments was determined from fixed $\mathrm{m}^{2}$ subplots by hand clipping to $5 \mathrm{~cm}$ on 15 May, 1 June, 15 June, $1 \mathrm{July}$, and $15 \mathrm{July,} 1984$ and 1985. All herbage samples were dried for $72 \mathrm{hr}$ at $55^{\circ} \mathrm{C}$ and weighed to estimate dry-matter production.

\section{Total Nonstructural Carbohydrates (TNC)}

Rhizomes from 6 big bluestem plants were collected from each plot every 2 weeks from 1 October 1983 to 1 May 1984 and 1 October 1984 to 1 May 1985 and monthly from 1 June to 1 September of both years. No plants were removed from the herbage production subplots. The rhizomes were placed in paper bags, dried for $72 \mathrm{hr}$ at $55^{\circ} \mathrm{C}$, and stored. After completion of the study, all rhizomes were cleaned with cold water washing, redried for 48 hr, roots were removed, and rhizomes ground with a Udy Cyclone Mill (1-mm mesh), and stored in a dark plastic vial. The rhizomes were analyzed for TNC $\left(\mathrm{mg} \bullet \mathrm{g}^{-1}\right)$ using a Technicon InfraAlyzer 400 (I/A 400) near-infrared reflectance spectrophotometer. The combination of wavelengths $1680,1778,1818,1940$, and $2348 \mathrm{~nm}$ were used for analysis. These gave the best multiple regression equation between laboratory values and predicted values with a 0.9871 multiple correlation coefficient (Wetzel 1983).

The I/A 400 was calibrated using 40 rhizome samples from the comparison standard treatment and selected across all sampling dates to insure a range of TNC concentrations (Wetzel 1983). The TNC content of these samples were predetermined using a dualenzyme method (Khaleeluddin and Bradford 1986). TNC concentrations have been shown to be highly correlated with pool sizes in another group of warm-season, tallgrass species, the Old World bluestems (Bothriochloa sp.) (Coyne and Bradford 1987).

\section{Soil Moisture}

Soil moisture was determined gravimetrically on 1 May, 1 June, 15 July 1984, and 1 May, 15 May, 15 June, 15 July 1985 . Two soil samples were taken from the $0-15 \mathrm{~cm}$ layer of each plot. The mean of those $\mathbf{2}$ samples was used in the analysis. No soil samples were taken from the herbage production subplots.

\section{Experimental Design and Analysis}

The study was conducted using a randomized complete block design with 3 blocks. A varying 2-3\% slope was the blocking factor. Data were statistically analyzed using SAS PROC GLM (SAS 1982) for unbalanced data. Where significant differences were found least squares mean separation was at $P=0.10$. Otherwise, probabilities of significance are reported.

\section{Results and Discussion}

\section{Herbage Production}

None of the winter mowing treatments reduced herbage yields in 


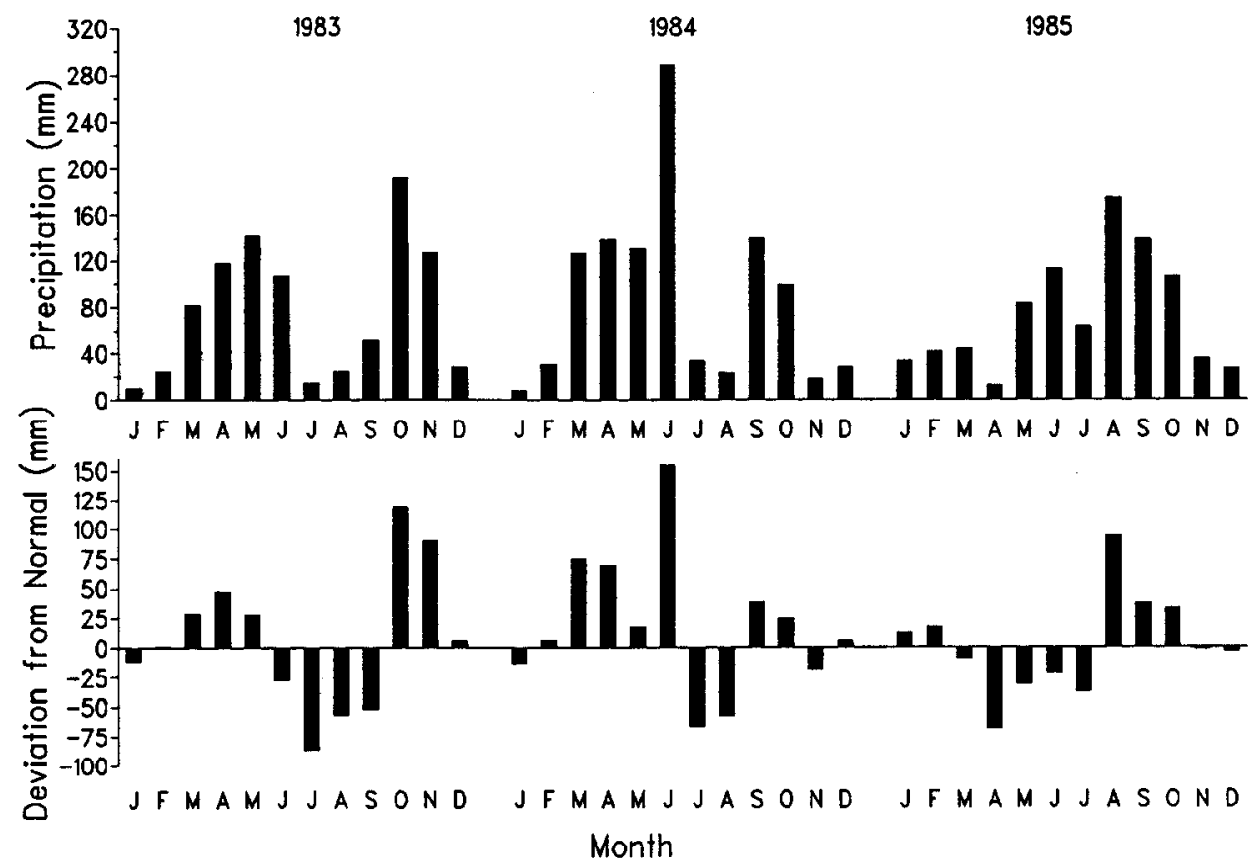

Fig. 1. Total monthly precipitation ( $\mathrm{mm}$ ) and deviation from normal at Manhattan, Kansas from 1983 through 1985.

the following season when compared to comparison standard $(P=0.0001)$, with the herbage yield averaging $3,145 \mathrm{~kg} / \mathrm{ha}$ on 15 July 1984 compared to $2,386 \mathrm{~kg} /$ ha on 15 July 1985 . Precipitation during May and June was higher in 1984 than 1985 (Fig. 1). It is likely that the greater available soil water during the 1984 growing season produced the higher herbage yields in 1984 versus 1985 .

\section{Total Nonstructural Carbohydrates (TNC)}

Two consecutive years of winter mowing did not significantly reduce TNC at any date for any treatment the second year $(P=0.66)$. Owensby et al. (1974) showed that intensive herbage removal by clipping through the growing season did not lower TNC reserves in big bluestem rhizomes until the second year following the clipping. In addition, the time at which cattle are returned to the IES pastures for winter grazing would be crucial. Owensby et al. (1977) showed that TNC in big bluestem rhizomes was lower during the growing season under IES, but the removal of cattle on $15 \mathrm{July}$ from the IES pastures gave adequate time for the big bluestem to regrow and translocate carbohydrates to the rhizomes before the onset of dormancy. They showed that under IES, the translocation of carbohydrates occurred primarily during September, with little movement thereafter throughout the winter season. Therefore, restocking before 1 October would result in lower carbohydrate storage and lower herbage production in the following season.

TNC in big bluestem rhizomes was lower in 1984 than 1985 $(P=0.03)$. Precipitation during July and August of 1983 and 1984 was lower than in July and August of 1985 (Fig. 1). Knapp (1985) reported that drought stress occurred in big bluestem from July to mid-August of 1983, during which net photosynthesis declined to near zero. Following precipitation in September, photosynthetic rates in big bluestem returned to about half the season maximum (Knapp 1985). Lack of precipitation in July and August 1984 also could have caused some drought stress in big bluestem. Lower photosynthetic rates caused by the mid-season drought likely produced less carbohydrate, resulting in less being translocated to rhizomes. The combination of possible lower carbohydrate storage in 1983 and the mid-season drought in 1984 probably caused the lower TNC in 1984 compared to 1985.

\section{Soll Moisture}

Plots on which herbage was returned to the soil surface follow- ing winter mowing had more total soil moisture than plots on which herbage was removed $(P=0.04)$. There were no differences among mowing treatments in total soil moisture in the $0-15 \mathrm{~cm}$ layer $(P=0.16)$.

\section{Conclusions}

Removing all herbage by mowing to $5 \mathrm{~cm}$ on a given date during the winter should be more detrimental to subsequent herbage yields than selective herbage removal through the winter by grazing. Since winter mowing to $5 \mathrm{~cm}$ on Flint Hills range did not reduce herbage yields or TNC concentration in big bluestem rhizomes the following season, cattle producers apparently can use IES pastures during the winter after sufficient regrowth has occurred.

\section{Literature Cited}

Coyne, P.I., and J.A. Bradford. 1987. Nitrogen and carbohydrate partitioning in Caucasian and WW-Spar Old World Bluestems. J. Range Manage. 40:353-360.

Hulbert, L.C. 1969. Fire and litter effects in undisturbed bluestem prairie in Kansas. Ecology 50:874-877.

Hulbert, L.C. 1985. History and use of Konza Prairie Research Natural Area. The Prairie Scout 5:63-93.

Khaleeluddin, K., and L. Bradford. 1986. Dual enzyme method for determination of total nonstructural carbohydrates. J. Assoc. Off. Anal. Chem. 69:162-166.

Knapp, A.K. 1985. Effect of fire and drought on the ecophysiology of Andropogon gerardii and Panicum virgatum in a tallgrass prairie. Ecology 66:1309-1320.

Launchbaugh, J.L., and C.E. Owensby. 1978. Kansas Rangelands: their management based on a half century of research. Kansas Agr. Exp. Sta. Bull. 622.

Owensby, C.E., J.R. Rains, and J.D. MeKendrick. 1974. Effects of one year of intensive clipping on big bluestem. J. Range Manage. 27:341-343.

Owemby, C.E., E.F. Smith, and J.R. Rains. 1977. Carbohydrate and nitrogen reserve cycles for continuous, season-long and intensive-early stocked Flint Hills bluestem range. J. Range Manage. 30:258-260.

SAS Institute, Inc.. SAS User's Guide' Basics, 1982 Edition. Cary, NC SAS Institute Inc., 1982.

Smith, E.F., and C.E. O wensby. 1978. Intensive-early stocking and seasonlong stocking of Kansas Flint Hills range. J. Range Manage. 31:14-17.

Wetzel, D.L. 1983. Near-inf rared reflectance analysis: sleeper among spectroscopic techniques. Anal. Chem. 55:1165A. 